\title{
CrimRxiv
}

\section{Crime Open Database (CODE)}

\section{Matthew Ashby}

Published on: Jun 29, 2021

DOI: $10.21428 / \mathrm{cb} 6 a b 371.96 \mathrm{~d} 7 f 3 \mathrm{cf}$

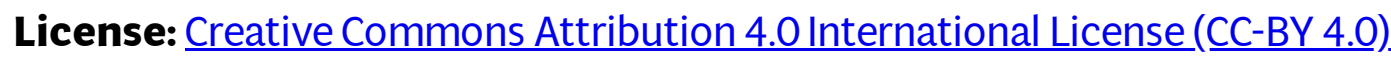


